\title{
LOS POSIBLES CAMINOS DE NIETZSCHE EN EL MODERNISMO
}

A la memoria de Luis Eyzaguirre

Es común calificar al modernismo como un movimiento carente de compromiso social. Algunos críticos han alimentado esta idea, como Guido Rodríguez Alcalá, quien afirma que, por el "culto de la subjetividad", los modernistas no pudieron "hacer una crítica radical del sistema vigente" . A su vez, John Beverley y Marc Zimmerman sostienen que los modernistas rechazaron la idea de un arte y una literatura al servicio de la política ${ }^{2}$. Antonio Cornejo Polar coincide con esta observación cuando describe la predilección finisecular por la estética como una tendencia elitista; para los modernistas, dice, su lenguaje era "el que mejor podía representar a la nación o a su sector más ilustrado"3. La búsqueda estética, me parece, no representa necesariamente una postura antisocial ni hegemónica, aunque sí puede ser una reacción ingenua. Creo que es necesario, ante la confusión que provocan afirmaciones como las que revisamos, indagar en el significado del modernismo.

Gerard Aching opina que la estética puede exponer y determinar alianzas políticas ${ }^{4}$, a esta expresión tendríamos que añadir la crítica a las actitudes burguesas y al sistema económico.

${ }^{1}$ En torno al "Ariel" de Rodó, Criterio Ediciones, Asunción, 1990, p. 25; las cursivas son suyas.

2 Literature and politics in the Central American revolutions, University of Texas Press, Austin, 1990, p. 42.

${ }^{3}$ Escribir en el aire. Ensayo sobre la heterogeneidad socio-cultural en las literaturas andinas, Editorial Horizonte, Lima, 1994, p. 160; las cursivas son suyas.

4 The politics of Spanish American "Modernismo": By exquisite design, Cambridge University Press, Cambridge, 1997, p. 3. 
En cuentos tan esteticistas como "El rey burgués" y "El velo de la reina Mab", del joven Rubén Darío, subyace una doctrina abiertamente antimaterialista. Sería difícil sostener lo apolítico de sus poemas posteriores, como "Salutación del optimista" y "A Roosevelt"; tampoco podemos dejar de pensar en José Martí y Manuel González Prada, quienes fueron abiertamente políticos, ni en José Enrique Rodó, el polemista modernista por antonomasia; no tiene sentido generalizar lo "asocial" de estos autores. Aunque sus composiciones brillan de una manera nueva con sus abundantes imágenes atrevidas, sería un error catalogarlos exclusivamente como estetizantes, y menos aún como representantes de la oligarquía.

El modernismo responde a la industrialización de la sociedad, cuyas características fueron el auge de la burguesía y la profesionalización de las letras. Para los poetas, según precisa Alberto Julián Pérez, el "modernismo es la clave para salir del atraso cultural, la marginación del mundo neocolonial latinoamericano, al menos, si no en la práctica, en la solución imaginaria que propone el arte a sus necesitados lectores" ${ }^{5}$. Sin embargo, como explica Mariátegui, "la burguesía quiere del artista un arte que corteje y adule su gusto mediocre" 6 . Dado que el elogio de lo ordinario no tiene cabida en la grandeza artística, los modernistas deciden encerrarse. Ivan A. Schulman explica el resultado de la relación entre aquella sociedad industrial y el artista idealista: "Debilitadas las normas y tradiciones antiguas por el positivismo y las ideas de la nueva ciencia experimental, el artista se sentía aislado y marginado en una cultura burguesa que lo convertía en un instrumento mediocre..."7.

En un ambiente hostil al arte, el escritor se esforzó por cultivar la belleza, atacada por ese mundo mecanizado, y expresar, de manera sutil, comentarios sociales. Tuvo que tomar ciertas precauciones para protegerse, creó mundos imaginarios, protegidos del comercialismo; a esta condición de alejamiento se podría llamar elitismo o hedonismo sólo si se olvida que representaba, asimismo, una postura defensiva que guardaba los ideales artísticos y filosóficos de un mundo amenazante. Fue la

${ }^{5}$ La poética de Rubén Dario. Crisis post-romántica y modelos literarios modernistas, Orígenes, Madrid, 1992, p. 74.

${ }^{6}$ El artista y su época, 10a ed., Empresa Editora Amauta, Lima, 1985, p. 13.

7 "Modernismo/modernidad: metamorfosis de un concepto", Nuevos asedios al modernismo, ed. I. A. Schulman, Taurus, Madrid, 1987, p. 21. 
reacción frente a una realidad que cada vez tenía menos sentido. Aching señala otro aspecto positivo de este "torremarfilismo": facilitaba cierta objetividad en el análisis de la sociedad ${ }^{8}$. En un ambiente modernista los escritores podían decir cosas que no se hubieran aceptado de otro modo.

No es mi intención, sin embargo, insinuar un modernismo único. Comúnmente se aceptan dos tendencias: una decadente, otra mundonovista, de acuerdo con José Miguel Oviedo ${ }^{9}$; una cosmopolita, otra americanista, según Aníbal González ${ }^{10}$. Tampoco existe un modernismo puro, como reconoce Max Henríquez Ureña, "en el movimiento modernista cabían todas las tendencias"11: romanticismo, positivismo, realismo, naturalismo, krausismo, paganismo, cristianismo, panteísmo, renanismo, parnasianismo y simbolismo ${ }^{12}$. Entendemos así que el modernismo es complejo y, dadas sus diversas fuentes, se desarrolló en tendencias distintas.

Hasta época muy reciente se distinguió a Manuel Machado, Juan Ramón Jiménez y el primer Valle-Inclán de escritores como Unamuno, Antonio Machado, Baroja y Azorín ${ }^{13}$, es decir que se opuso el eticismo al esteticismo. En lo que toca a esta vi-

${ }^{8}$ Op. cit., p. 16.

9 "The modern essay in Spanish America", The Cambridge history of Latin America, eds. R. González Echevarría \& E. Pupo-Walker, Cambridge University Press, Cambridge, 1996, t. 2, p. 366.

10 "Literary criticism in Spanish America", The Cambridge history of Latin America, t. 2, pp. 444-445.

${ }^{11}$ Breve historia del modernismo, F.C.E., México, 1954, p. 17. Allen W. PHILLIPS vuelve a repetir esta característica sintética del modernismo en "El arte y el artista en algunas novelas modernistas", RHM, 34 (1968), p. 757.

12 Véanse, para el romanticismo, PÉREZ, op. cit.; positivismo, LuIs EyZAGUI$\mathrm{RRE}$, El héroe en la novela latinoamericana del siglo Xx, Editorial Universitaria, Santiago de Chile, 1973, p. 26; naturalismo, Henríquez UreÑa, op. cit., p. 17; krausismo, Richard A. CARDWELl, "Juan Ramón, Ortega y los intelectuales", HR, 53 (1985), 329-350 y Tomás G. ORIA, Martí y el krausismo, Society of Spanish and Spanish-American Studies, Boulder, CO, 1987; panteísmo, T. WARD, "El pensamiento religioso de Rubén Darío: un estudio de Prosas profanas y Cantos de vida y esperanza", RevIb, 146/147 (1989), 363-375; renanismo, G. Rodríguez Alcalá, op. cit., pp. 59-63; y simbolismo, José Emilio Pacheco, "Introducción”, Antología del modernismo, 1884-1921, UNAM, México, 1970, t. 1, p. xviii.

${ }^{13}$ Los estudios recientes se han liberado en algo de esta tendencia. Ahora, cómodamente se incluye a Valle-Inclán en la Generación del 98. Véanse, por ejemplo, los estudios recogidos en La Generación del 98 frente al nuevo fin de siglo, ed. J. Torrecilla, Editions Rodopi, Amsterdam-Atlanta, 2000. 
sión, la actitud de Guillermo Díaz-Plaja es representativa: para él, lo ético representa "un instrumento de mejoría de la humanidad" mientras que el esteticismo se orienta "hacia la sensación"14. En esta línea, Beverley y Zimmerman cuestionan el carácter elitista, formalista y apolítico del modernismo peninsular con respecto a la Generación del $98^{15}$. Constituiría un descuido, me parece, negar las ideologías sociales en los estetas, pues es posible la estética con ideología.

Los esfuerzos de catalogación y diferenciación tienden a negar las corrientes filosóficas y sociales que definen a las literaturas. Desde el principio, Federico de Onís rechazó este tipo de división. Según él, el modernismo no fue una escuela ni un movimiento, sino una época "anárquica, crítica e innovadora" que resultó de una "honda transformación histórica que se inició en el mundo hacia 1885"16. Al concebir el modernismo como un momento histórico, Onís ofrece la única forma de entenderlo: un conjunto de corrientes literarias, filosóficas, económicas y sociales que estuvieron en boga durante el penúltimo fin de siglo ${ }^{17}$. En el presente estudio me centraré en la relación del modernismo con la filosofía, y, más específicamente, con la figura de Friedrich Nietzsche.

A pesar de sus rasgos estetizantes, el modernismo fue capaz de tener una visión filosófica que se manifestó en un lenguaje embellecido artísticamente. Juana Sánchez-Gey observa que mostró un "deseo de belleza" sin dejar de ser "convincente y

14 Modernismo frente a Noventa y Ocho, Espasa-Calpe, Madrid, 1951, p. 11.

15 Op. cit., p. 55. Las últimas aperturas en esta polémica (modernismoGeneración del 98) se resumen en Gonzalo Sobejano, "Auge y repudio del 98”, La crisis española del fin de siglo y la Generación del 98. Actas del Simposio Internacional, eds. A. Villanueva y A. Sotelo, Universitat de Barcelona, Barcelona, 1999, pp. 15-31. Importante en la reconceptualización del modernismo será Nelson OrRinger, "Taming the swan: Redefining Hispanic modernism in the world context", Southeastern Quarterly Review, de próxima aparición; su "Introduction to Hispanic modernisms", BHS, 79 (2002), 133-148 también es útil.

16 "Contemporaneidad de González Prada", RHM, 4 (1938), 5-7; esp. pp. 5-6.

17 Otros escritores han adoptado esta postura. Véanse Manuel Pedro GonzÁlez, Notas en torno al modernismo, UNAM, México, 1958; RicARdo Gullón, Direcciones del modernismo, Gredos, Madrid, 1963, e Ivan A. Schulman, "Reflexiones en torno a la definición del modernismo", Martí, Dario y el modernismo, eds. I. A. Schulman y M. P. González, Gredos, Madrid, 1969, pp. 23-59. 
profundo en las ideas"18. Al contrario de lo que sostiene DíazPlaja ${ }^{19}$, entre todas las corrientes doctrinarias, el nihilismo es uno de los elementos primordiales en la ideología modernista. Tal confluencia fue aparente en el año de 1905 cuando José de la Riva-Agüero ubicó el auge del simbolismo y el decadentismo "en plena fiebre del nietzscheanismo" 20 . No sorprende entonces que para Gonzalo Sobejano la tendencia "que pervive en Darío con más consecuencia" sea el aristocratismo nietzscheano ${ }^{21}$. Seis años antes de la muerte del filósofo, Darío intentó corregir tal omisión, elogiándolo en uno de los variados artículos que aportó a La Nación de Buenos Aires. El poeta nicaragüense admiraba al filósofo prusiano y lamentaba que no recibiera la atención adecuada: “iTriste suerte la de Nietzsche! Durante su vida - su vida moral-, sus trabajos no logran la boga y el triunfo que él ambicionaba..."22. Huelga decir que el nietzscheanismo de Darío no siempre es positivo pues desemboca en temor al final de Cantos de vida y esperanza, cuando el poeta, sufriendo del Weltschmerz, pide a Dios que libere a la humanidad de los "superhombres de Nietzsche" 23.

Esta vacilación con respecto a la figura del filósofo se da en otros intelectuales modernistas, como por ejemplo en Rodó y en González Prada. El uruguayo, a pesar de dudar de ciertos elementos del nietzscheanismo, reconoce el poderoso impacto del filósofo, "que tan profundo surco señala en la que podríamos llamar nuestra moderna «literatura de ideas»..."24. Como he dicho en otro lugar, el autor de Páginas libres muestra una

18 "El modernismo filosófico en América”, CuA, 1993, núm. 41, p. 110.

${ }^{19}$ Según el famoso crítico, "es evidente que Nietzsche interesa a la mentalidad intervencionista y pedagógica del Noventa y Ocho, tanto como repugna al modernismo". En el mismo lugar afirma que los modernistas prefieren a Verlaine sobre el filósofo germánico (cf. G. Díaz-Plaja, op. cit., p. 175).

${ }^{20}$ Carácter de la literatura del Perú independiente, Librería Francesa Científica Galland, Lima, 1905, p. 234.

${ }^{21}$ Nietzsche y España, Gredos, Madrid, 1967, p. 203.

22 "Los raros: Nietzsche", Escritos inéditos de Rubén Dario, ed. E. K. Mapes, Instituto de las Españas, New York, 1938, p. 54. Este ensayo no llegó a incluirse en el libro Los raros.

${ }^{23}$ R. DARío, Poesías completas, Editorial Claridad, Buenos Aires, 1987, t. 2, p. 576 .

24 José EnRIQue Rodó, Ariel con Calibán por Roberto Fernández Retamar, ed. Abelardo Villegas, SEP-UNAM, México, 1982, pp. 46-47. En adelante, las referencias a este texto serán por autor y página entre paréntesis en el texto. 
relación de atracción y repulsión con respecto a Nietzsche ${ }^{25}$. Aun con la recepción parcial del filósofo prusiano, su influencia fue sustancial porque cuando los modernistas no partían de su filosofía, reaccionaban en contra suya.

El impacto que Nietzsche tuvo en España fue tan profundo que Sobejano dedicó un tomo grueso al tema, sin agotarlo. Como he señalado en otro momento, la estética modernista de la Sonata de otoño de Valle-Inclán organiza la filosofía nihilista de Nietzsche ${ }^{26}$. Adelante comentaré algunos pormenores de su recepción en la Península aunque, como Sobejano deja a un lado a todas las figuras hispanoamericanas (con la excepción notable de Darío), quisiera concentrarme en ciertos rumbos nietzscheanos en las Américas, sin omitir del todo a España, sobre todo cuando sirva de punto de comparación.

Es conveniente preguntarnos, antes de continuar, cómo un escritor alemán pudo tener tanta influencia en Hispanoamérica, donde las primeras traducciones de su obra se publicaron años después de sus ediciones alemana, francesa y española. La primera traducción, publicada por el novelista Xavier Icaza Jr. ${ }^{27}$, en 1919, se encuentra en el número 1 del tomo 10 de la revista mexicana Cultura, y apareció con el título Federico Nietzsche. La obra es una selección de los capítulos de Así hablaba Zaratustra, traducción de un tal Juan Fernández (véase infra) ${ }^{28}$. En seguida aparecieron dos traducciones en Argentina: Opiniones (1922) y Wagner: combatido por Nietzsche (1924) ${ }^{29}$.

Estas fechas, 1919-1924, son demasiado tardías para considerarlas como fuentes para la mayoría de la producción modernista hispanoamericana. Lo que sí encontramos son artículos críticos interpretando los libros publicados en Europa.

25 ThOmas WARD, La anarquía inmanentista de Manuel González Prada, Universidad Ricardo Palma-Editorial Horizonte, Lima, 2001, pp. 177-187.

26 T. WARD, "La Sonata de otoño: un hito en el desarrollo hacia el nihilismo activo", NRFH, 34 (1991), 1051-1065. Investigaciones posteriores pueden encontrarse en RAMÓN EsPEJO-SAAVEDRA, "Entre el mito y la desilusión: el discurso histórico simbolista de Águila de Blasón y Romance de lobos", Hecho Teatral, 1 (2001), 37-53. Un nuevo acercamiento a Nietzsche y España se ofrece en Gonzalo Navajas, "La ética del 98 ante el siglo xxi: de Unamuno a Antonio Muñoz Molina", en La Generación del 98 frente...

27 Icaza fue autor de novelas psicológicas y regionalistas como Dilema (1921), Gente mexicana (1924) y Panchito Chapopote (1928).

${ }^{28}$ Federico Nietzsche, ed. Xavier Icaza, Jr., Editorial México, [México], 1919.

29 Opiniones, Buenos Aires, 1922 y Wagner, Claridad, Buenos Aires, 1924 (Los pensadores, año 2, núm. 78). 
Tanto Darío como Rodó comentaron la obra de Nietzsche, el primero en el ya citado ensayo porteño (1894) y el segundo en su influyente Ariel (1900). El "Nietzsche" de Darío refiere a "ensayos y estudios", "recuerdos y biografías" sobre el filósofo. Además, el poeta cita largamente a la hermana del filósofo, Elisabeth Förster Nietzsche ${ }^{30}$, quien concluía en aquel momento un experimento socialista que duró ocho años en el Paraguay. En este artículo, que parece haberse escrito bajo las presiones de las fechas límite que caracterizan al periodismo, Darío reprodujo un largo párrafo de Jorge Brandes y sugirió a sus lectores que leyeran las versiones originales, o las traducciones, de Nietzsche. En especial recomendó el estudio de Henri Albert ${ }^{31}$. Dos años más tarde apareció De sobremesa, novela nietzscheana del colombiano José Asunción Silva, en la cual se exponía un conocimiento, quizás un tanto superficial, del superhombre, de la moral más allá del bien y del mal, y de Así hablaba Zaratus$\mathrm{tra}^{32}$. En esta novela se comenta explícitamente la difusión de "la voz terrible de Nietzsche" (p. 168). El peruano Riva-Agüero incluyó los aforismos y las máximas de Nietzsche en su Carácter de la literatura del Perú independiente. Otro limeño, Óscar Miró Quesada, compuso variados libros y artículos filosóficos, entre otros, "El altruismo de Zaratustra" (1909) y "Salomón Nietzsche" (1909) 33 .

Estas fechas resultan muy tardías; de manera que el nietzscheanismo en Iberoamérica se remontaría a otras fuentes como España y Francia. En cuanto a la primera, Latinoamérica refleja lo que la crítica anticipó de la lectura de los textos de Nietzsche $^{34}$. Los catalanes mostraron cierto interés hacia el filósofo, como se comprueba en autores como Pompeyo Gener y Joan

${ }^{30}$ R. DARío, "Los raros: Nietzsche", pp. 54, 55.

${ }^{31}$ Georg Morris Cohen Brandes, F. Nietzsche. Eine Abhandlung über Aristokratischen Radikalis [1888], en Menschen und Werke, Literarische Anstalt, Frankfurt/M., 1895; Henri Albert, "Friedrich Nietzsche", Mercure de France, 1893, núm. 7, 46-64.

32 De sobremesa, Ediciones del Sol y de la Luna, Bogotá, 1965, pp. 167, 168, 172, 201, 208.

33 Los dos publicados en Contemporáneos, 1909, núm. 1, 2-6 y 338-340, respectivamente.

${ }^{34}$ En cuanto a este párrafo y el siguiente, en lo que toca a publicaciones en Madrid y Barcelona, tendrían forma muy distinta si no tuviéramos a mano el extenso libro de Gonzalo Sobejano, Nietzsche en España. Es interesante notar que el nietzscheanismo entró en España mayormente por Barcelona, lo mismo que el modernismo nativo. 
Maragall. En el caso de Gener hubo plagios abiertos de la obra de Nietzsche en sus libros críticos (1893-1900) ${ }^{35}$. En el de Maragall, entre sus varias tentativas, figuró su "Nietzsche" (1893) ${ }^{36}$.

En la capital, mucho de este debate ocurrió en las páginas de La España Moderna, aunque no siempre. Salvador Canals publicó comentarios sobre Nietzsche en El Heraldo de Madrid en 1894. Dos años más tarde Eduardo Gómez de Baquero hizo observaciones sobre Nietzsche en La España Moderna ${ }^{37}$, publicación en la que Juan Valera entregó su artículo "El superhombre" (1897). Entre los colaboradores de esta revista madrileña figuraron Ramiro de Maeztu, quien acuñó su "Estudio sobre Sudermann" en $1898^{38}$, y Fernando Araujo, con su "Filosofía de Nietzsche", en el mismo año ${ }^{39}$. Como Valera, Francisco Giner, en "La moral del super-hombre" de $1898^{40}$, mostró una actitud negativa ante Nietzsche; también aportaron ideas al debate Baroja ${ }^{41}$ y Clarín ${ }^{42}$. Cabe decir que en 1910, muy tarde ya, se tradujo del francés la prestigiosa Filosofía de Nietzsche de Henri Lichtenberger (véase infra) ${ }^{43}$.

En cuanto a la obra de Nietzsche, Pedro González Blanco tradujo varios textos que difundió en la casa editorial F. Sempere de Valencia, donde también publicó la primera traducción de Nietzsche que encontramos en España: Más allá del bien y del mal (1885). Tradujo Aurora: Meditación sobre los prejuicios morales (¿1886?), Humano, demasiado humano (1909), La gaya ciencia (1910), El caso Wagner, Nietzsche contra Wagner, Opiniones y sentencias diversas (¿1910?-¿1919?) y El anticristo ${ }^{44}$. Otra traduc-

35 Véase G. Sobejano, Nietzsche, pp. 37-45.

36 Pamphilos [Joan Maragall], "Nietzsche", L'Avenç, 15-31 de julio de 1893, núms. 13-14. Véase también Sobejano, Nietzsche, pp. 84-88.

37 "Crónica literaria”, La España Moderna, 1896, núm. 88, 115-116.

${ }^{38}$ En La España Moderna, 1898, núm. 113, 5-28.

${ }^{39}$ La España Moderna, 1898, núm. 119.

${ }^{40}$ En Obras completas, La España Moderna, Madrid, 1925, t. 11, pp. 277279. Sobre el mismo tema, también en Obras completas, "La acción moral de la juventud", de 1899, p. 147.

41 "Nietzsche y la filosofía", de 1899, en Obras completas, Biblioteca Nueva, Madrid, 1948, t. 8, pp. 853-856. También, "El éxito de Nietzsche", en "El tablado de Arlequín" (1904), Obras completas, t. 5, pp. 18-19. Consúltese, asimismo, G. Sobejano, Nietzsche, pp. 62-65.

${ }^{42}$ Véase Nietzsche, pp. 83-84.

${ }^{43}$ Trad. por J. E. Matheu, Madrid, 1910.

${ }^{44}$ De El anticristo se desconoce al traductor, como todos, apareció en F. Sempere, Valencia-Madrid, ¿1900?-¿1930? 
ción que apareció en Valencia de autoría dudosa es Asi hablaba Zaratustra (1906) ${ }^{45}$. A Joan Maragall se debe la primera versión catalana de Aixi va parlar Zarathustra (1893) ${ }^{46}$. Hubo otros esfuerzos en Barcelona: El anticristo y el ascetismo cristiano (1903), Así hablaba Zaratustra, Más allá del bien y del mal, y Humano, demasiado humano, todos en 1905. Por su parte, La España Moderna en Madrid publicó Así hablaba Zaratustra (1900), junto con Más allá del bien y del mal (1901 o 1902), La genealogía de la moral (1902), Últimos opúsculos de Federico Nietzsche (1904), La gaya ciencia (1905), y El viajero y su sombra $(1907)^{47}$. El primero es original de Juan Fernández que, como ya mencionamos, terminó publicándose en México. Sobejano dedica numerosas páginas a resolver la identidad de esta figura misteriosa, sin conseguirlo del todo ${ }^{48}$.

Fuera de traducciones y comentarios en castellano, la ruta más probable de penetración de las ideas de Nietzsche fue Francia. Es una relación espinosa la de Nietzsche y este país ya que coincide con los años posteriores a la guerra franco-prusiana (1870-1871). Sin embargo, unas sesenta ediciones de sus libros aparecieron en Francia entre 1880 y 1920, es decir los años que impactarían en el modernismo. Como en Hispanoamérica y España, la influencia de Nietzsche en Francia antecedía a la traducción de sus obras. Señalemos algunas pautas.

Quizás los primeros intentos de difundirlo en Francia sean dos artículos anónimos en la Revue Critique (1874), según los cuales el pensamiento juvenil de Nietzsche parece favorecer la cultura francesa sobre la alemana ${ }^{49}$. Este temprano interés no se desarrollaría mayormente hasta el final del siglo, cuando aparecieron ensayos en revistas como Revue Bleue (1891), Revue des Deux Mondes (1892), Mercure de France (1893), L'Ermita-

45 Asi hablaba Zaratustra. (Un libro para todos y para nadie), Prometeo, Valencia, 1906.

${ }^{46}$ Se trata de limitados capítulos publicados en la revista L'Avenç, 1893, núms. 20/21.

${ }^{47}$ Así hablaba Zaratustra, Más allá del bien y del mal, La genealogía de la moral, Últimos opúsculos de Federico Nietzsche, La gaya ciencia, y El viajero y su sombra, La España Moderna, Madrid, 1900, 1901 o 1902, 1902, 1904, 1905, y 1907, respectivamente. Los traductores de estas obras son diferentes y algunos anónimos. No he podido hojear la traducción de Juan Fernández de Así hablaba Zaratustra, pero G. Sobejano ha visto una reimpresión del año 1906, consúltese Nietzsche, pp. 67-74.

48 Véase Nietzsche, pp. 67-74.

49 Núm. 39, p. 206, y núm. 46, pp. 318-319. 
ge (1898) y Les Études Religieuses (1899) ${ }^{50}$. Algunas de éstas como el Mercurio de Francia publicaron múltiples ensayos sobre el filósofo germano. Entre los libros que tuvieron impacto están los Écrivains étrangers (1898) de Wyzéwa, La philosophie de Nietzsche (1898) de Lichtenberger, Les maîtres de la pensée contemporaine (1904) de Bourdeau, Nietzsche et la réforme philosophique (1904) de Gaultier, En lisant Nietzsche (1904) de Faguet, Apollôn ou Dionysos (1905) de Seillière, La philosophie de Frédéric Nietzsche (1917) de Huan, y el copioso Nietzsche: sa vie et sa pensée (19201931) de Andler51.

Estos comentarios se publicaban paralelamente con las obras de Nietzsche, aunque, como en otros lugares, llegaron con retraso respecto a las interpretaciones ${ }^{52}$. La primera obra de Nietzsche que apareció en Francia fue Le cas Wagner (1892) ${ }^{53}$, la segunda, una edición de Paul Lauterbach y Adrien Wagnon, A travers l'oeuvre de Frédéric Nietzsche (1893) ${ }^{54}$. Habría que esperar más de un lustro para que la Sociedad Mercurio de Francia publicara la mayoría de las obras del filósofo-poeta. Ofreció al

50 TÉodor de WyzÉwa, "Frédéric Nietzsche, le dernier Métaphysicien", Revue Bleue, 1891, núm. 48, 586-592; G. Valbert, "Le Docteur Frédéric Nietzsche et ses griefs contre la société moderne", Revue des Deux Mondes, 1892, núm. 113, 677-689; Henri Albert, "Friedrich Nietzsche", Mercure de France, 1893, núm. 7, 46-64; JAcQues Morland, "Étude sur Nietzsche", L'Ermitage, 1898, núm. 12, 394-402; y S. J. Léonce Grandmaison, "La religion de l'égoïsme, étude sur Frédéric Nietzsche”, Les Études Religieuses, 1899, núm. 81, 798-817.

51 T. De Wyzéwa, Écrivains étrangers, Perrin, Paris, 1898; Henri LichtenberGer, La philosophie de Nietzsche, Félix Alcan, Paris, 1898; Jean Bourdeau, Les maîtres de la pensée contemporaine, Félix Alcan, Paris, 1904; Jules DE Gaultier, Nietzsche et la réforme philosophique, Mercure de France, Paris, 1904; ÉmiLE FAGUET, En lisant Nietzsche, Société Française d'Imprimerie, Paris, 1904; Ernest SEILliÈre, Apollôn ou Dionysos: étude critique sur Friedrich Nietzsche et l'utilitarisme impérialiste, Plon, Paris, 1905; Gabriel Huan, La philosophie de Frédéric Nietzsche, Bossard, Paris, 1917; Charles Andler, Nietzsche: sa vie et sa pensée, 6 ts., Bossard, Paris, 1920-1931. Sobre estas primeras repercusiones se pueden consultar Pierre Boudot, Nietzsche et les écrivains français, 1930 à 1960, Aubier-Montaigne, Paris, 1970; Eric Hollingsworth Deudon, Nietzsche en France: l'antichristianisme et la critique, 1891-1915, University Press of America, Washington, 1982, y Douglas Smith, Transvaluations: Nietzsche in France, 1872-1972, Clarendon Press, Oxford, 1996.

${ }^{52}$ D. Sмiтн hace la misma observación, op. cit., p. 38.

53 Éds. Daniel Halévy et Robert Dreyfus, Paris, 1892. No he podido verificar este dato que encontré en D. Sмiтн, op. cit., p. 39.

54 Éds. Paul Lauterbach et Adrien Wagnon, A. Schulz, Paris, 1893. 
público Par delá le bien et le mal (1898), Humain, trop humain (1899), La généalogie de la moral (1901), Ainsi parlait Zarathoustra (1901), L'origine de la tragédie ou héllénisme et pessimisme (1901), Le gai savoir (1901), Le voyageur et son ombre, opinions et sentences mêlées... (1902), La volonté de puissance (1903), Aurore: réflexions sur les préjugés moraux (1901), Le crépuscule des idoles (1904), Considérations inactuelles: David Strauss (1907), y Ecce Hommo: suivi de poésies (1909) ${ }^{55}$. Cito sólo las primeras ediciones ya que la mayoría de estas obras salieron en tirajes posteriores, hasta 1919.

En fin, es dudoso que los modernistas latinoamericanos leyeran ediciones publicadas en el continente americano antes de 1919, pero sí pudieron leer y escribir sobre Nietzsche en las revistas y diarios. También diversas publicaciones de Alemania, Francia y España llegaron a Latinoamérica, especialmente a México y a Buenos Aires. Varios modernistas dominaban el francés, entre ellos Gutiérrez Nájera, González Prada, Silva y Casal. Y hablaban otros idiomas, como el caso de González Prada con el alemán o Silva con el inglés. Otra posibilidad, no muy estudiada, es el influjo del nietzscheanista italiano, Gabriel D'Annunzio $^{56}$. Los modernistas que viajaban por España o Francia pudieron acudir a las mismas fuentes disponibles para los españoles y franceses, éstos son los orígenes del nietzscheanismo que más impactaron.

Con una excepción me concentraré en lo que se ha llamado la primera generación modernista. Mi propósito no es probar específicamente que uno u otro escritor de esta generación fue nietzscheano. Esta doctrina finisecular no era monolítica, pues cada modernista la amoldó según sus creencias personales. Tampoco quiero sugerir que estos artistas hayan sido lectores ávidos del filósofo, él no originó el nietzscheanismo, sólo organizó y enfocó el Zeitgeist. Los modernistas compartieron el mismo espíritu de la época que Nietzsche glosó, y recordemos que el modernismo, tal como lo describe Federico de Onís, no es una escuela sino un momento histórico. Se puede

55 De 1904 también Le cas Wagner-Nietzsche contre Wagner-L'Antéchrist y de 1907, De l'utilité et des inconvénients des études historiques. Todas estas obras se publicaron en París por la "Société du Mercure de France" con diversos editores.

${ }^{56}$ Para la relación extranietzscheana entre el escritor italiano y el modernismo consúltese SANDro ABATE, "Darío y D'Annunzio: estudio comparativo de dos poemas", Hij, 1999, núm. 20, 29-47. 
decir que tanto Azorín como Valle-Inclán son escritores nietzscheanos, sólo que esto es más evidente en el primero que en el segundo, se trata de una cuestión de matices, no de absolutos.

Numerosos escritores de la llamada primera generación modernista expresan el pensamiento de Nietzsche sin haberlo leído (aunque varios sí lo conocieron) porque sus ideas estaban en el aire, respondiendo a la creciente crisis que produjo la industrialización global. En general, la respuesta a este peligro puede reducirse a siete áreas temáticas: 1) una crisis moral; 2) lo macabro; 3) el lujo; 4) la decadencia; 5) el arte como valor supremo; 6 ) el artista y el rebaño y 7) lo espiritual. Veremos en seguida la complejidad de estos temas que son a la vez modernistas y nietzscheanos.

La crisis moral. Desde siempre el ser humano ha necesitado una doctrina que le dé un punto de referencia. Éste ha sido el papel del cristianismo. Nietzsche explica el fenómeno. La moral cristiana "concedía al hombre un valor absoluto, por oposición a su pequeñez" 57 , pero con el ocaso de las religiones, la moral se destruye (Nietzsche, p. 60). Es forzoso reconocer, entonces, que "toda lucha moral contra el vicio, contra el lujo y el crimen, incluso contra la enfermedad misma" es una lucha quijotesca (Nietzsche, p. 49). Sin la moral que lo encubre, surge la "veracidad" de la vida. Es un proceso circular. La posibilidad de ver la realidad, "se vuelve finalmente contra la moral, descubre su teología, su consideración interesada" (Nietzsche, p. 34), nos vemos forzados a contemplar el mundo tal como es.

$\mathrm{Al}$ extinguirse la moral, la teología cristiana pierde su vigencia; sin ella, y frente a la desnudez de una vida sin sentido, se descubre la nada. Éste es un tema que los modernistas consideran. En su poema más famoso, José Asunción Silva establece un paralelo entre la tumba, la muerte y la nada: "Era el frío del sepulcro, era el frío de la muerte / era el frío de la nada..."58. También Julián del Casal recoge este motivo cuando descifra la sensación de enfrentarse con la nada. A diferencia de Silva, la nada en Casal se experimenta antes de morir. En su controvertido poema "Nihilismo", la vida se pinta como un sendero

${ }^{57}$ La voluntad del poderío, ed. D. Castrillo Mirat, trad. A. Froufe, EDAF, Madrid, 1981, p. 33. En adelante, cito en el texto por autor seguido de página.

58 Spanish American modernista poets. A critical anthology, ed. Gordon Brotherston, 2nd ed., Bristol Classical Press, London, 1995, p. 65. 
oscuro: "después de atravesar la selva obscura / Beatriz no ha de mostrarme el Paraíso"59. Sin la teología, la humanidad se expulsa del Edén para siempre; la tierra, entonces, es estéril: "mi vida... / es un cielo que nunca tuvo estrellas, / es un árbol que nunca tuvo flores" (Casal, t. 1, p. 201). El "cielo" y el "árbol” representan la divinidad y la tierra respectivamente. Los dos carecen de sentido, tanto que "si miro al horizonte, todo es sombra, / si me inclino a la tierra, todo es cieno" (Casal, t. 1, p. 202). La destrucción del cielo (el bien) y de la tierra (el mal) es eco de la filosofía nietzscheana en contra de la moral cristiana que expira cuando la fe se apaga. En "La urna", Casal documenta esta condición:

\section{Muerta ya mi fe pasada y la pasión que sentía, veo, con mirada fría que está la urna sagrada como mi alma: vacía}

(Casal, t. 1, p. 44).

Se pone de manifiesto una existencia sin sentido donde Dios ha abandonado al poeta. Casal, como recuerda Robert Jay Glickman, conserva numerosos elementos del sistema católico de valores (véase Casal, t. 2, pp. 288-299), aunque coincide con Nietzsche, sin mencionarlo, cuando reconoce la crisis de la moral en las sociedades modernas. La relación de Silva con el filósofo poeta es más clara en su novela De sobremesa: una amante (jalemana!) dice a su hombre que le fascina "su desprecio por la moral corriente" y le llama un Übermensch. En la página anterior, el superhombre le había recomendado que viviera "más allá del bien y del mal" 60 . Destruido el dualismo cristiano, la fe y la moral, el individuo debe resignarse ante la nada, que existe dentro y fuera del alma.

Aunque Martí no se interesó por la filosofía de Nietzsche, por lo menos no lo cita en su vasta obra, en su ensayo elegíaco a Emerson describe la ausencia de moral en los norteamericanos y lo dibuja como superhombre nihilista: "No obedeció a

59 The poetry of Julián del Casal: A critical edition, ed. R. J. Glickman, The University Presses of Florida, Gainsville, 1976, t. 1, p. 202. En adelante, cito en el texto por autor, tomo y página.

60 Op. cit., pp. 201, 200. 
ningún sistema, lo que le parecía acto de ciego y de siervo; ni creó ninguno, lo que le parecía acto de mente flaca, baja y envidiosa. Se sumergió en la naturaleza, y surgió de ella radiante. Se sintió hombre, y Dios, por serlo" 61 . El Emerson de Martí niega todo régimen de valores y así cumple con las características del nihilismo activo.

Liberado de la moral, el individuo entra en conflicto con la religión tradicional. Este antagonismo, en palabras de Nietzsche, "trae como resultado un proceso de desintegración" (Nietzsche, p. 34). Roto el dogma, la moral se pone en crisis, y "nos parece que el universo se desvaloriza[,] "pierde su sentido'..." (Nietzsche, pp. 10-11). Aceptando un mundo sin "sentido", los modernistas, como observa Octavio Paz, demuestran "indiferencia, a veces abierta hostilidad, ante el cristianismo"62. No hay ningún escritor que ostente mejor esta actitud que González Prada cuando proclama que "el catolicismo es el enemigo"63; de manera parecida, Casal se opone al dogma cuando en Rimas el corazón se enamora más "de [una] regia pecadora" que "de una pastora" (Casal, t. 1, p. 251). Esta hostilidad se suaviza en otros modernistas y toma la forma de un desinterés frente al cristianismo/lo cristiano, lo que les dio la libertad de escribir obras con valores que para un creyente serían inmorales.

La Sonata de otoño de Ramón del Valle-Inclán es ejemplo de esta tendencia. En esta novela, el Marqués de Bradomín acude a las creencias ocultas (acepta el poder curativo de las yerbas), participa en una relación incestuosa (tiene relaciones con su prima), e inicia nuevos amores inmediatamente después de morir su amada (con otra prima). Tales acciones son sumamente ofensivas al cristianismo, representan el rechazo de los valores cristianos. Este aristocratismo modernista intenta superar el concepto burgués de la moral, un eco débil de los grandes ideales del pasado.

La compleja relación entre la moral, el cristianismo y Nietzsche se aclara un poco en un contexto positivista. Gonzá-

61 J. Martí, Obras completas, Editorial Nacional de Cuba, La Habana, 1963-1973, t. 13, p. 20. En adelante, las referencias a las Obras completas serán por autor, seguido de tomo y página.

62 "El caracol y la sirena", Cuadrivio, $5^{\mathrm{a}}$ ed., Joaquín Mortiz, México, 1980, p. 28.

${ }^{63}$ Páginas libres, en Obras, ed. L. A. Sánchez, PetroPerú, Lima, 1985, t. 4, p. 25. En adelante, las referencias a las Obras serán por tomo y página. 
lez Prada, como el filósofo, representa una ruptura con la moral cristiana, aunque a diferencia de aquél, el peruano acepta la moral si ésta se deriva de la ciencia: "no cabe diferenciación entre Ciencia y Moral desde que las reglas de moralidad se derivan de los principios sentados por la Ciencia" (González Prada, t. 1, p. 138). Aunque elogia a la figura de Jesucristo (t. 1, pp. 302-307), su postura frente a la Iglesia es nihilista ${ }^{64}$. La moral modernista, entonces, puede ser anticlerical sin dejar de ser espiritual; la distancia que se mide entre el clero y el espíritu también puede inspirar la crisis moral.

Lo macabro. Para Octavio Paz el modernismo es una "estética del lujo y de la muerte" 65 . La inclinación hacia lo lúgubre se explica otra vez con Nietzsche. Sin la moral que protege al individuo, éste tendrá que enfrentarse directamente con la transitoriedad de la vida. Para el cristianismo los seres humanos no tienen que pensar en la muerte sino como el principio de la vida eterna; por él, como señala Nietzsche, "el hombre se ha liberado de la muerte..." (p. 147). Desacreditado el cristianismo, una persona comienza a perder la fe al aceptar su propio fin como un aspecto de la vida.

Hay dos modernistas que se preocupan por la muerte: José Martí, quien no leía a Nietzsche, y González Prada, para quien sí era familiar. Como éste, el pensador limeño ve la vida como un sendero transitorio por el que viajan los humanos, quienes no son más que "eternos caminantes, / Aves de paso"; esta temporada en la tierra engloba "mil y mil generaciones" (González Prada, t. 5, p. 189). Este proceso se repite infinitas veces y cada alma, al concluir su residencia temporal, se enfrenta con su propia destrucción. El poeta lo acepta, desea "morir consciente y libre, en medio de frescas rosas" (González Prada, t. 5, p. 346).

Lo macabro toma una forma menos arrogante en Casal, la voz poética de quien, en "La mayor tristeza", muere "sin creer en Dios ni en la mujer hermosa", sin poder liberarse del "azote de la humana suerte" (Casal, t. 1, p. 40). En otro lugar, el poeta ejerce su voluntad besando el cadáver de su "hermosa adorada”, en este momento fúnebre, el amor y la pasión son sustan-

64 Véase T. WARD, "El poder protocristiano", en La anarquía inmanentista, pp. 153-176.

65 Op. cit., p. 23. 
ciales, tanto así que el amante se inclina sobre el "féretro luciente", besando la "yerta boca" con tal emoción que sufre convulsiones (Casal, t. 1, pp. 14-15). Lo macabro es más intenso y perverso en otro poema, cuando recuerda con desdén los amores de su juventud. Hablando de aquellas mujeres afirma: "Hallo siempre satánicos placeres / en disecar sus muertos corazones" (Casal, t. 1, p. 49).

Esta necrofilia se asocia con el cristianismo en los dos poetas, el peruano y el cubano. En el primero, el rechazo de los símbolos cristianos se relaciona con un muerto: "llantos", "quejas", "ayes", "rituales" y "cirios" (González Prada, t. 5, p. 346). En el segundo, una "urna sagrada", adornada con "la imagen de María", resulta un objeto vacío de significado porque es la fe la que muere, no la persona (Casal, t. 1, p. 44). Las posturas anticristianas suponen la superación del nihilismo pasivo (el cual, según indica Nietzsche, se asocia con la religión tradicional), y demuestran que estos poetas han adoptado el nihilismo activo en sus búsquedas.

El lujo. Con la negación de la moral y el utilitarismo, el arte modernista aceptó y glorificó la suntuosidad: "las letras se llenaron de lujos", como observa Anderson Imbert ${ }^{66}$. Cualquier lector de estas obras reconoce la predilección por los adornos. Un autor característico en este sentido es Darío. En "El velo de la reina Mab" hay "un carro hecho de una sola perla", "petos dorados", "alas de pedrería”, "oro", "trojes de riqueza", y "piedras preciosas" 67 . En otro momento, la opulencia viene de las culturas indígenas o se deriva de las orientales. Un buen ejemplo de chinofilia aparece en otro de sus cuentos, "La muerte de la emperatriz de la China". Este relato presenta a una mujer "como una joya humana", cuya pareja es un escultor que trabaja con finos mármoles que convierte en "japonerías y chinerías". En su estudio se describen artefactos asiáticos: cuchillos, pipas, máscaras, y enanitos; el objeto más majestuoso es la grandiosa "emperatriz" anunciada en el título ${ }^{68}$. En el poema "Marina", de Casal, hay "un brazalete de oro, constelado / de diamantes,

66 Historia de la literatura hispanoamericana, F.C.E., México, 1982, t. 1, p. 398.

${ }^{67}$ En Cuentos y poesías, ed. C. García Prada, Ediciones Iberoamericanas, Madrid, 1961, pp. 44-48.

68 En Cuentos y poesias, pp. 65-74. 
rubíes y zafiros" (t. 1, p. 203); estas imágenes lujosas son representativas de aquellos tiempos. Aun en una autora considerada "naturalista", como Clorinda Matto de Turner, existen imágenes netamente modernistas ${ }^{69}$, se habla de encaje, hadas, marfil, rubíes, zafiros y esmeraldas ${ }^{70}$. En una escritora tan comprometida esta elegancia representa una belleza que refina y libera a la sociedad de los agravios de la pobreza.

El lujo importa porque puede superar el fin de la existencia terrenal y preservar un estado de belleza mientras la muerte inicia la etapa de descomposición. En Casal, por ejemplo, cuando presenta un cadáver, este es "nacarado" (t. 1, p. 203); un muerto desnudo se desintegrará antes en el tiempo que uno opulento y adornado. Esta actitud se adelanta en una novela del segundo modernismo, La rosa muerta, de la peruana Aurora Cáceres. Antes de que la protagonista, Laura, muera de un tumor uterino, va con un pintor para que éste le conceda el lujo de preservar su belleza más allá de la muerte. Su retrato será "la Venus más perfecta que queda del arte contemporáneo" 71 . En general, los adornos rinden un tributo inmemorial a la muerte, hermosean por igual la realidad burguesa de la que el artista quiere liberarse, y protegen contra la pobreza: "me abruma un porvenir de miseria y de hambre", admite uno de los cuatro artistas del cuento de $\mathrm{Mab}^{72}$.

La decadencia. Entre la muerte y el lujo, la moral se pone en duda. Sin la moral que encubre la decadencia, ésta palpita visiblemente. Es un proceso mediante el cual, según Matei Calinescu, "modernity turns against itself and, by regarding itself as decadence, dramatizes its own deep sense of crisis"73. Es por esto que la época modernista mostró gusto "por una realidad fea y enfermiza"74. Es quimérico luchar contra la decadencia, dado

${ }^{69}$ Boreales, miniaturas y porcelanas, Juan A. Alsina, Buenos Aires, 1902, p. 25.

70 Véase "La equitativa", Leyendas y recortes, Lima, 1893, pp. 125-132.

${ }^{71}$ Pról. de Amado Nervo, Casa Editorial Garnier Hermanos, Paris, 1914, cap. 17.

72 R. Darío, "El velo de la reina Mab", p. 47.

73 Faces of modernity: Avant-Garde, decadence $\mathcal{E}^{\circ}$ kitsch, Indiana University Press, Bloomington, 1977. Calinescu dedica un capítulo al concepto de la decadencia en Nietzsche, desde una perspectiva diversa a la que aquí planteo, pp. 178-195.

${ }^{74}$ Cf. E. Anderson Imbert, op. cit., t. 1, p. 399. 
que "es absolutamente necesaria y propia de todas las épocas, de todos los pueblos" (Nietzsche, p. 49) ${ }^{75}$, no se puede combatir contra ella porque es la hez del esfuerzo humano: "Cuanto con más energía y audacia vaya adelante más rica será en fracasos, en deformidades, y más cercana estará de la caída..." (Nietzsche, p. 49). En una palabra, el mismo sobrepujamiento humano fomenta la decadencia en la sociedad y en el arte.

La vida, por lo tanto, se revela sin encubrimientos. Darío representa el Zeitgeist cuando, en el "Poema de otoño", canta: "sentimos la vida pura, clara, real..."76. Por una vida transparente se verifican la muerte, el dolor, la enfermedad y la decadencia, no hay que temer a tales elementos sino aceptarlos. Los escritores de la época modernista aportaron esta manera innovadora de apreciar la vida.

En España el modernismo tuvo un carácter particular. Como la sociedad europea desarrollaba su economía con más rapidez que la latinoamericana, aceptó con más ahínco la idea del superhombre y su mundo decadente. Esta decadencia se asoció con el paso del feudalismo al capitalismo, cuando la aristocracia cedió su poder a la burguesía. Mientras el sector burgués cobraba poder económico, la aristocracia caía en un estado de abulia, enfermedades y deterioro. En la Sonata de otoño de Valle-Inclán, el narrador deja ver este proceso, no lo cubre con ninguna moral. El simbolismo se manifiesta cuando presenta el "oloroso cementerio de San Clodio de Brandeso"77, lugar de entierro de sus antepasados aristocráticos; la grandeza de la familia ha decaído tanto que se preserva únicamente en las lápidas que quedan. Aunque el linaje de su familia se origina en don Roldán, el héroe que aparece en el Cantar de Roncesvalles y la Chanson de Roland, el Marqués de Bradomín desconoce esta herencia (Valle-Inclán, p. 51). Cuando sus primas, Concha e Isabel, sostienen una larga conversación sobre un pasado nostálgico que comparten, no evocan más que una "olvidada y luenga parentela” (Valle-Inclán, p. 61). En fin, que es tal la degeneración que

75 Nietzsche no es el único escritor de aquellos años que se interesó por la decadencia. También fueron influyentes Joris-Karl Huysmans, A rebours, Charpentier, Paris, 1884, y Max Nordau, Dégénérescence, Félix Alcan, Paris, 1894.

${ }^{76}$ Poesías completas, t. 2, p. 650.

77 Sonata de otoño, Espasa Calpe, Madrid, 1969, p. 12. En adelante, cito por autor y página. 
las cuatro grandes familias han terminado estableciendo relaciones incestuosas entre los dos primos, el Marqués y Concha.

La atmósfera decadente se da no sólo en actitudes y prácticas, sino también en elementos materiales, como las tumbas. En el palacio aristocrático hay "una fragancia delicada y antigua", una "derruida escalinata" y algunos "arcones antiguos" (Valle-Inclán, pp. 16-17, 34, 35). Estos componentes descriptivos padecen los estragos del tiempo. Las condiciones económicas de la capilla también se van deteriorando, aún más durante la vida del Marqués, quien percibe el proceso de decaimiento y admite: "Yo aún recuerdo aquel tiempo cuando había capellán en el Palacio" (Valle-Inclán, p. 74). Con la decadencia, ya no se preservan los fondos económicos para mantener el palacio y su capilla, su degeneración coincide con la superación de la moral cristiana.

Observamos otros elementos de este tipo en el jardín. El narrador dice que "las flores empezaban a marchitarse" y "parecía difundir por el jardín un sueño pacífico de vejez, de recogimiento y de abandono". En este triste contorno serpentea un "sendero umbrío" (Valle-Inclán, p. 32), que simboliza la vida enferma de la principal residente del palacio: Concha. En la Sonata de otoño, de este modo, se combinan armónicamente la muerte, el lujo y el ocaso de las sociedades modernas; la obra es en esencia una versión novelada de la filosofía de Nietzsche, con una falta de valores éticos. Nosotros también sabemos que el descenso de la aristocracia, que Valle-Inclán reproduce en la novela, resulta del nuevo poder burgués.

También en las obras latinoamericanas podemos ver esa decadencia. En "Desolación", Casal presenta una capilla que anticipa la de Sonata, una "lóbrega capilla" en la cual "el incensario" ya "no humea", su torre, "agrietada y amarilla", permanece en el silencio y el abandono (Casal, t. 1, p. 55). La decadencia cobra un valor preciso en Asunción Silva, ya que,

Las cosas viejas, tristes, desteñidas, sin voz y sin color, saben secretos de las épocas muertas, de las vidas que ya nadie conserva en la memoria... ${ }^{78}$

Lo que tienen en común los modernistas peninsulares y americanos es una nostalgia por los tiempos pasados y una tris-

78 G. Brotherston, op. cit., p. 61. 
teza ante la ausencia de Dios, que el artista rectifica para dar otra vez sentido a la vida.

Otra novela modernista representa este tema de manera ejemplar. Me refiero a La rosa muerta de Aurora Cáceres, la cual indaga en este problema desde la perspectiva femenina. La trama consiste en una sucesión de visitas de Laura a varios ginecólogos en Francia y Alemania, todas las salas de espera están atiborradas de enfermas. El cuerpo achacoso de Laura recuerda a las mujeres pálidas de Valle-Inclán. Los médicos son aventureros románticos (como el doctor Barrios), científicos fríos (como el doctor Blumen) o individuos sin ética profesional (el consultorio del doctor Castel se convierte en un lecho de encajes donde Laura se entrega a él). Toda la atmósfera de la novela se crea con trajes lujosos, especialmente los de la protagonista, con las enfermedades, y con la decadencia del ambiente y de los personajes. Dado que la autora es peruana, es significativo que la obra se publique en París, que tenga lugar en Francia y Alemania, y que la protagonista de la novela sea andaluza. No obstante sus esfuerzos por curar la enfermedad, ella no puede liberarse de la decadencia de su cuerpo sino por el artificio.

El arte como valor supremo. Con el apogeo del nuevo ímpetu industrial para los negocios, con su espíritu práctico para la vida, la medida por la que se juzga al arte es por su "utilidad"; si la creación artística no es útil para el comercio, no tiene valor. Nietzsche comenta el fenómeno: cuando se obliga al arte a ser práctico, pierde su grandeza, las creaciones padecen una "absoluta falta de originalidad"; la condición del arte "en el mundo moderno" queda reducida a un estado de "entenebrecimiento" (Nietzsche, p. 32). Los modernistas pretendieron resolver este problema apartándose del espíritu burgués que, por su naturaleza, fomentaba la vulgaridad; el arte era su único refugio, y esta idea la expresó bien Casal: "el alma grande, solitaria y pura / que la mezquina realidad desdeña, / halla en el Arte dichas ignoradas" (t. 1, p. 45). La búsqueda de la elevación del espíritu fue una respuesta a la infeliz realidad de un mundo que poco a poco iba industrializándose; sólo exteriormente los modernistas adoraron la forma, debajo permanecía una honda crítica social. Vayamos de nuevo a Nietzsche.

El filósofo expresamente rechaza la doctrina del "arte por el arte". Para él, es un "principio peligroso" porque aparta el ideal de la realidad. La actitud de Nietzsche frente al arte se 
asemeja a su postura frente a la moral, ni el uno ni el otro pueden ser un fin porque asumirían la forma de "Dios", apartándose de la vida. La creación artística es y debe ser inseparable de la vida, de hecho, la función del arte es servir como un medio para "hacer la vida más intensa", elevándola en el proceso (Nietzsche, pp. 184-185). Esta idea nietzscheana también aparece en Sudamérica, pero con un matiz distinto. Mercedes Cabello de Carbonera, escritora peruana catalogada como realista, pero también perteneciente a la época modernista, sigue al filósofo prusiano en su repudio al "arte por el arte", aboga por una literatura que sirva "a la moral y al progreso" 79 . Obviamente, Nietzsche no se hubiera expresado en estos términos. Sin embargo, el moralismo positivista de Cabello no constituye una actitud religiosa sino que, de acuerdo con las doctrinas del filósofo, representa un medio para llegar a un fin: la corrección de la putrefacción social. Vistos de esta manera, la moral y el arte se conciben como medios, por lo que se puede establecer un paralelo entre la tratadista y el autor de La voluntad del poderío.

Los modernistas abrazaron este ideal y lo combinaron con el aprecio de la belleza: los latinoamericanos protestando por su escasez, los españoles respondiendo a la crisis de 1898. El iberoamericano que más se preocupó por la belleza fue José Enrique Rodó, pues colocó la moral, la hermosura y la vida en un solo plano: "sería un motivo superior de moralidad el que autorizaría a proponer la cultura de los sentimientos estéticos, como un alto interés de todos" (Rodó, p. 29). La moral en el uruguayo se limita a la transformación cultural. Como recuerda Ottmar Ette, lo ético y lo estético se unen en él ${ }^{80}$, considérese esta receta: "La perfección de la moralidad humana consistiría en infiltrar el espíritu de la caridad en los moldes de la elegancia griega" (Rodó, p. 32). Al sintetizar la belleza y la caridad Rodó reconoce la dimensión económica de los problemas sociales y el efecto que ésta produce en la estética. Este tipo de moral sincrética no dista mucho de la de Nietzsche. Cuando una creación artística sirve de medio para una postura axiológica, como el arte nietzscheano, puede "hacer la vida más inten-

${ }^{79}$ La novela moderna. Estudio filosófico, ed. A. Tamayo Vargas, Ediciones Hora del Hombre, Lima, 1948, p. 34.

80 "«Así habló Próspero»: Nietzsche, Rodó y la modernidad filosófica de Rodó”, CuH, 1994, núm. 528, 49-62; véase p. 53. 
sa”. De la misma manera, la caridad como medio representa una actitud sociofilosófica ante la vida.

Para mejorar la condición humana de una manera agradable y justa es preciso modificar la estética y la ética, que inextricablemente se enlazan. Esta idea era tan de la época que aparece en el prenietzscheanismo de José Martí, en el cual "la hermosura física" conduce a "la hermosura moral" (Martí, t. 13, p. 23). Pero tal correspondencia es irrealizable cuando la miseria impide apreciar la elegancia. La moral modernista frecuentemente es una forma de perfeccionar la vida. Como dice Nietzsche, es un "medio", porque existe una relación recíproca entre la moral y la vida. En fin, según el ensayista cubano: "El objeto de la vida es la satisfacción del anhelo de perfecta hermosura; porque como la virtud hace hermosos los lugares en que obra, así los lugares hermosos obran sobre la virtud" (loc. cit.).

La ética es imprescindible para lograr la justicia económica, sin ésta, las condiciones obligatorias para gozar de la belleza son inalcanzables. Otra vez, la moral modernista no es necesariamente teológica, con frecuencia encuentra su origen en la vida o en la ciencia.

Como con la moral, cuando el arte muestra las formas más exquisitas de la vida sirve de modelo para elevarla. Es paradigmático que el Círculo Literario de González Prada se transformara en un partido político radical, la Unión Nacional; la estética sirve así para un fin ético. La idea central de aquel momento era que el arte podía mejorar las condiciones sociales.

El rebaño y el artista. Con el apogeo del industrialismo, las masas que se integraban a las fábricas no tenían tiempo ni derecho a la educación. La sociedad carecía de estética y las empresas de ética, como respuesta, los modernistas se concibieron como una minoría selecta de maestros que se levantaron sobre lo que Nietzsche llamó "la especie inferior ('rebaño', 'masa', 'sociedad')" (Nietzsche, p. 43). El filósofo diría que la noción de "rebaño" resultó del cristianismo, para nosotros surgió igualmente con la industrialización rápida del mundo. Con el auge de la manufactura, explotó concomitantemente el interés por las ciencias sociales. No es coincidencia que Saint Simon, filósofo del industrialismo, y su discípulo Auguste Comte, inventaran la sociología. Nietzsche percibe con claridad la relación entre una sociedad mecánica sin alma y el nacimiento de las ciencias 
sociales: "toda nuestra sociología no conoce ningún otro instinto que el del rebaño, es decir, el de la suma de los ceros, en que cualquier cero tiene los mismos derechos" (Nietzsche, p. 57). Los modernistas responden a esta realidad dudando de la fe en la sociología para regenerar la sociedad. Van en contra de la sociedad para superar la mediocridad inherente a las vidas comunes, carentes de significado.

Es preciso leer a Rodó desde esta perspectiva. J. M. Oviedo ve como característica negativa la tendencia digresiva y abstracta que Rodó cultivó en su Ariel, porque omitió las realidades sociológicas, económicas o políticas. Lo distingue en este sentido del abiertamente social González Prada ${ }^{81}$. Su perspectiva, sin embargo, no puede ser económica ni política en un sentido cotidiano porque es nietzscheana; su ideología opera en un nivel superior a la mera ciencia social, a la que Nietzsche desprecia, por esto parece "abstracto". Cuando Rodó se lee en un mismo contexto con Nietzsche (y Krause y Renan ${ }^{82}$, etc.), su ideología (¿su filosofía?) resulta muy clara.

Como dije, los modernistas impulsaron al artista para elevar a las agrupaciones plebeyas. La fuente de esta idea otra vez está en Nietzsche. Si el cristianismo favorecía la igualdad de todas las almas ante Dios, el nietzscheanismo, en cambio, defendía a ciertos individuos capaces de sobrepujarse y crear un arte selectivo (Nietzsche, p. 153). Ellos podrían crear pautas para rescatar al resto de la humanidad de la mediocridad industrial.

Los modernistas coincidieron con Nietzsche en su lucha contra la insignificancia, como Martí en su crítica a las masas inertes. En su ensayo sobre Emerson, sin referirse al filósofo poeta, hace la siguiente pregunta: “¿Qué habían de parecerle... esos perezosos u hombres de rebaño, que no usan de sus ojos, y ven por los de otro?” (t. 13, p. 20). Rodó va más allá y abiertamente cita al filósofo nihilista, de esta manera: "Nietzsche opone al ideal de una humanidad mediatizada, la apoteosis de las almas que se yerguen sobre el nivel de la humanidad como una viva marea" (Rodó, p. 43). Los artistas ofrecen un

81 Véase J. M. Oviedo, op. cit., p. 369.

82 Véanse, T. WARD, "El concepto krausista de la belleza en el Ariel de José Enrique Rodó", Actas del XXIX Congreso del Instituto Internacional de Literatura Iberoamericana, ed. Joaquín Marco, Promociones y Publicaciones Universitarias, Barcelona, 1994, t. 2, v. 1, pp. 545-558 y G. Rodríguez AlcAlá, op. cit., p. 75 . 
medio por el cual este "hombre de rebaño" puede hallar nuevos caminos y forjar su propio destino. Por lo tanto, se acusa al modernismo de ser esteticista por su tendencia frecuente a mostrarnos cómo ver. Pero además, los modernistas señalaron qué era lo que había que ver, actitud que representaría asimismo una postura ética. De este modo, ofrecieron, al hombre común, una guía estético moral para que se liberara de lo rutinario. Por su estética paradigmática, los modernistas fueron educadores éticos que ejercieron su profesión por medio de la palabra escrita.

No es que estos escritores hayan rechazado la igualdad, la negaron cuando implicaba una fea circunstancia, sin altos ideales, sin un estilo elevado de la vida. Nietzsche la descarta por ser concepto cristiano y Rodó porque anula la hermosura. Siendo católico y burgués, el uruguayo no puede seguir a Nietzsche al pie de la letra. Aduce que la democracia impide el cultivo de la belleza, la democracia es un engaño porque parte de "aquella falsa concepción de igualdad" que limita al individuo (p. 42). Rodó anticipa de esta manera los argumentos de La rebelión de las masas de Ortega ${ }^{83}$. La igualdad en la miseria económica, cultural y espiritual no es mejor que las pautas elevadoras, por elitistas que parezcan, a pesar de las jerarquías que establecen.

Pensando en los Estados Unidos, el autor de Ariel llega a sus conclusiones sobre la democracia ${ }^{84}$ : no funciona en Norteamérica porque "su personaje representativo se llama 'Yo quiero', como el 'superhombre' de Nietzsche". Al emparentar el "Yo quiero" con el superhombre, Rodó se aparta en algo de Nietzsche. Esta divergencia se explica por la oposición materia/espíritu. El "superhombre" estadounidense se caracteriza por "la originalidad y la audacia" (Rodó, p. 55) en sus deseos materialistas, pero no en los espirituales. Rodó opina: "cuando la democracia no enaltece su espíritu por la influencia de una fuerte preocupación ideal que comparta su imperio con la

83 Para la relación entre Nietzsche y Ortega y Gasset, en cuanto al concepto de artista, véase HowARD Giskin, "El hombre selecto como artista en Ortega y Gasset y en Nietzsche”, NRFH, 34 (1985-86), 181-193.

${ }^{84}$ Muchos han comentado la actitud de Rodó frente a los Estados Unidos. Véanse, Alberto Zum Felde, Índice crítico de la literatura hispanoamericana: los ensayistas, Editorial Guarania, México, 1954, pp. 291-293; EMIR RodríGuEz Monegal, "Sobre el anti-imperialismo de Rodó", RevIb, 38 (1972), 495-501; David W. Foster, "Procesos de literaturización en Ariel de Rodó", Explicación de Textos Literarios, 1981-82, núm. 10, 5-14, esp. p. 10; y J. M. Oviedo, op. cit., pp. 366-370. 
preocupación de los intereses materiales, ella conduce fatalmente a la privanza de la mediocridad" (Rodó, p. 38). Como Martí, Rodó promueve la concomitancia de la mejora material y espiritual, no puede cultivarse la una sin la otra, hacerlo implicaría espiritualismo sin relación con el mundo, o, de lo contrario, materialismo sin ideales.

Se perciben diferencias y semejanzas entre Nietzsche y el ensayista modernista. Si el filósofo desprecia a la clase-rebaño, Rodó, por su cristianismo, debe abrazarla. No obstante esta divergencia, los dos pensadores coinciden en el concepto de una jerarquía artística para guiar a los grupos menospreciados. ¿Cómo determinar quiénes son los artistas y dónde deben encontrarse en la jerarquía social? "Todo espíritu superior se debe a los demás en igual proporción que los excede en capacidad de realizar el bien" (Rodó, p. 46). Es decir existe una jerarquía innata que determina la posición de cada individuo en la sociedad, esta postura positivista no tiene que ver con la sobrevivencia del más apto, sino con un impulso para "realizar el bien". Pero el bien y la belleza son vulnerables en el mundo industrial, entonces la nobleza espiritual debe protegerse frente a la democracia igualitaria:

La selección espiritual, el enaltecimiento de la vida por la presencia de estímulos desinteresados, el gusto, el arte, la suavidad de las costumbres, el sentimiento de admiración por todo perseverante propósito ideal y de acatamiento a toda noble supremacía, serán como debilidades indefensas allí donde la igualdad social que ha destruido las jerarquías imperativas e infundadas, no las substituya con otras que tengan en la influencia moral su único modo de dominio y su principio en una clasificación racional (Rodó, p. 38).

Para Rodó, la mentalidad de rebaño alimenta una psicología en que nadie puede expresar un sentimiento elevado en la vida ni apreciar la finura, e impide que el artista ofrezca pautas estéticas y éticas cuando su función ideal es ser vocero de la moral. La idea jerárquica no representa aquí un desprecio a la plebe, no, el pensador aboga por la elevación de las masas populares, sólo que se opone a su estancamiento en una "igualdad" que no se acerca a los encumbrados ideales de la belleza. La postura de Rodó coincide en esto con las de González Prada y Darío. Por ejemplo, en "El velo de la reina Mab" traslada el problema a la ficción. En este cuento de Darío no existe sino 
una "muchedumbre que befa", ante tal realidad, "los cuatro hombres flacos, barbudos, e impertinentes", aun siendo dotados de los poderes encantadores, necesitan del hada Mab para convertir su tristeza en felicidad, sólo de este modo son capaces de crear arte (pp. 47-48). El hada, como las "jerarquías imperativas" de Rodó, es indispensable para infundir la perfección, primero en los artistas, quienes a su vez la inculcarán en las agrupaciones plebeyas.

Lo espiritual. Un producto del nihilismo activo es el espiritualismo. A los modernistas, "cualquier esfuerzo espiritual les entusiasmaba" ${ }^{85}$. Este rasgo decisivo no viene al modernismo únicamente por Nietzsche, entre sus varias raíces cuenta con el romanticismo ${ }^{86}$, el panteísmo oriental y el panteísmo krausista ${ }^{87}$. Resulta también del nuevo interés en Jesucristo el hombre, el Jesucristo inmanente, tendencia representada en importantes ensayos de Tolstoi, Proudhon, Renan, Strauss, Bakunin y González Prada. Pero el que repercute destacadamente en el concepto espiritual de los modernistas es el nietzscheanismo, un concepto que no tenía nada que ver con la moral cristiana, una especie de euforia por penetrar en los misterios del cosmos. Con Nietzsche se destaca la exigencia de instalar "un grado relativo de cultura espiritual" en la vida (Nietzsche, p. 61). Esta "cultura espiritual" aparece en Rodó como "la espiritualidad de la cultura" a la que, partiendo del filó-

${ }^{85}$ E. Anderson Imbert, op. cit., t. 1, p. 399.

86 Véanse, por ejemplo, T. WARD, "Nature and civilization in Sab and the Nineteenth-Century novel in Latin America”, Hf, 1999, núm. 126, 25-40.

${ }^{87}$ El racionalismo armónico se puede percibir en Alas (España), Rodó (Uruguay), Martí (Cuba), Alejandro Deustúa (Perú) y Eugenio María de Hostos (Puerto Rico). Clarín figura aquí porque tenía contacto sustancial con los primeros escritos modernistas de Salvador Rueda, José Santos Chocano, Rubén Darío y Ramón del Valle-Inclán. Un buen resumen de sus ideas frente al incipiente modernismo se encuentra en MARÍA BÁEz MARCO, "Consideraciones sobre la posición de Clarín ante el Modernismo", Las relaciones literarias entre España e Iberoamérica, Instituto de Cooperación Iberoamericana, Madrid, 1987, pp. 311-319. Para el krausismo en estos autores véanse T. WARD, "El krausismo como base de la relación literatura-vida en $L a$ Regenta", ULULA, 1986, núm. 2, 91-109 y "El concepto krausista de la belleza en el Ariel de José Enrique Rodó"; T. G. Oria, op. cit.; José Luis Abellán, "La dimensión krauso-positivista en Eugenio María de Hostos", CuA, 1989, núm. 16, 58-66; y aunque no menciona el krausismo, sí los conceptos fundamentales, Jack Himelblau, "Alejandro O. Deustúa: An aesthetic vision of education”, Revista Interamericana de Bibliografía, 1970, núm. 20, 417-426. 
sofo, concibe como "el término ideal a que asciende la selección humana" (Rodó, p. 13), por esto tuvo que criticar países que no tenían ideales espirituales ni estéticos. El ideal rodoniano se representa en el arte, el artista y el espiritualismo, jamás en el materialismo o el utilitarismo. Esta espiritualidad nietzscheana toma forma en el culto a lo magistral en Rodó, a la poesía en Darío y a la mujer en Valle-Inclán.

A despecho de sus variados y desiguales contactos con Nietzsche, los modernistas González Prada, Martí, Casal, Silva, Darío, Rodó, Valle-Inclán y Cáceres crearon un arte nihilista ${ }^{88}$, debido a ello "la palabra modernismo apunta una transitoriedad" 89 que destruye un estado de cosas para avanzar hacia otro. He aquí un tema toral en el modernismo: la sociedad contemporánea es tan despreciable que no queda sino destruirla o negarla, éste fue el mensaje principal de González Prada. Por ello, numerosos escritores finiseculares fueron nihilistas activos, no repudiaron todo, pero sí lo que impedía su búsqueda aristocrático espiritual para regenerar la sociedad.

Como he señalado, la prosa de los modernistas es filosófica. Adoptaron una postura crítica ante lo que he llamado nietzscheanismo, y de su sistema axiológico seleccionaron diversos elementos. El modernismo, por tanto, no podía ser literatura de evasión; si por un lado González Prada y Azorín subordinaron el arte a las ideas, por el otro Darío y Valle-Inclán sometieron las ideas al arte, pero entre éticos y estéticos no hubo diferencia absoluta, sólo relativa. Detrás del arte modernista palpitaron ideas muy profundas, ideas que llegaron con frecuencia al nivel de Nietzsche; lo que hicieron los modernistas fue ofrecer una respuesta refinada a la fealdad de la modernidad, con la esperanza de que fuese beneficiosa para el enriquecimiento espiritual de las muchedumbres.

THOMAS WARD

Loyola College

${ }^{88}$ Con excepción de Cáceres, he concentrado la atención en el llamado primer modernismo. Existen otros "senderos posibles" en el segundo modernismo, especialmente en Leopoldo Lugones y Amado Nervo. Hacen falta nuevos estudios sobre este tema.

89 E. Anderson Imbert, op. cit., t. 1, p. 399. 
